\title{
ASEAN Regional Diplomacy and Cooperation in Reducing Poverty and Building Resilience: Towards Covid-19 Recovery
}

\author{
Desy Churul Aini \\ Faculty of Law \\ Lampung University \\ Lampung, Indonesia \\ desy.churulaini@fh.unila.ac.id
}

\begin{abstract}
ASEAN as an international organization that accommodates regional areas in achieving its goals carries out various beneficial collaborations with external parties (which are often called dialogue partners) be it state, organizational, institutional, sub-regional, regional, or international cooperation. Especially in the current pandemic situation, collaboration is needed to overcome the crisis caused by the coronavirus pandemic by maximizing the ASEAN organization. The formulation of the problem in this paper is how the position, function, and authority of ASEAN as an international organization, as well as the cooperation that has been carried out by ASEAN in dealing with the COVID-19 pandemic crisis. ASEAN is a regional organization that aims to promote economic growth, social progress, and cultural development in the Southeast Asian region through multilateral cooperation. Moreover, it serves as a non-political platform to maintain peace and stability among its member states and external partners. Several efforts have been discussed at the regional level by ASEAN to overcome the COVID-19 pandemic which has spread throughout the country, especially in the ASEAN Region. For example, the Joint Statement on Defense Cooperation against Disease Outbreak. On April 14, 2020, the Special ASEAN Summit (Summit) through a virtual conference resulted in the Declaration of the Special ASEAN Summit on Coronavirus Disease 2019 (COVID-19). Furthermore, on the same day, the ASEAN Plus Three (APT) meeting was also held virtually. In addition, there are also other collaborations such as the ASEAN Comprehensive Recovery Framework (ACRF) which was initiated by the ASEAN Secretariat in 2020.
\end{abstract}

Keywords-ASEAN, COVID-19, ACRF

\section{INTRODUCTION}

Regionally the Indonesian territorial position classifies Indonesia to be one of the members of the International Organization of the Southeast Asian region, namely ASEAN. As implemented on the official website of ASEAN (Association of Southeast
Asian Nations) or also known as the league of Southeast Asian Nations. ASEAN is a territorial organization whose sole purpose is to accommodate cooperation between 10 nations all across Southeast Asia [1]. The organization was established in Bangkok, Thailand on August 8, 1967, by 5 founding nations, Indonesia represented by Adam Malik, Malaysia represented by Abdul Razak, Philippines represented by Narcisco Ramos, Singapore represented by S. Rajaratnam, and Thailand represented by Thanat Khoman. ASEAN was established through the Bangkok Declaration that was represented by foreign ministries, as ASEAN progressed, the members of ASEAN gradually increases, Brunei Darussalam joined ASEAN on the 8th of January 1984, Vietnam on the 28th of July 1995, Laos and Myanmar on the 23rd of July 1997, and Cambodia on the 30th of April 1999. ASEAN was established to fulfill the strong whims of the founding nations which are to create a peaceful, safe, stable, and prosperous Southeast Asian region. These whims arose due to the regional situation during the 1960's era which was bombarded with conflicts in regards to Ideologies and this era depicts the catastrophic state between Southeast Asian nations, and if left unchecked will disrupt the regional stability and will henceforth obstruct development [2].

ASEAN acts as an organization that accommodates and assists its member's goals, the organization has been conducting numerous cooperation that is beneficial to the external parties which are called dialogue partners, be it a collaboration between states, organizations, institutions, sub-territory, territory, and International. Collaboration. Especially where nowadays nations are faced with a worldwide pandemic, there needs to be a collaborative effort to properly assess the issues, crises, presented by the Coronavirus pandemic through optimizing regional organizations such as ASEAN. 
Towards the end of 2019, the news was flooded by the founding of a new strain of virus called the Coronavirus originating from a wholesaler seafood market in the Hubei Province of Tiongkok specifically the town of Wuhan [3]. In the beginning, the virus was given a name based on its genetic structure that was known as the 2019 novel coronavirus (2019-nCoV) [4], but that name would be changed to simply the coronavirus. The coronavirus itself classifies as a group of viruses that attacks both humans and animals. The infection of the virus is associated with an infection to the respiratory system signifies by as simple as coughing and mild flu to a Middles East Respiratory Syndrome (MERS) and a Severe Acute Respiratory Syndrome (SARS) [5]. The coronavirus causes a unique infectious sickness called COVID-19. The term Coronavirus Disease 2019 (COVID-19) was inaugurated by the World Health Organization (WHO) on the 11th of February 2020 [6].

There isn't a single member of ASEAN that is not affected by the virus. According to the data on the WHO website, as of the 23rd of February 2021 at 09.52 Am; the total infection cases of Covid-19 worldwide have reached a wapping 111.279.860 lives, with a total death toll of 2.466.639. Indonesia has the highest confirmed Covid-19 cases in South East Asia with a total of 1.288 .833 cases, and a death toll of 34.691, The Philippines place second with a total of 563.456 cases of Covid-19, and a total death toll of 12.094 [7].

Malaysia has a total of 285.761 confirmed cases of infection, with a total death toll of 1.062. As for Myanmar, they have confirmed 141.750 cases of infection, with a total death toll of 3.196, Singapore has a total of 59.879 confirmed cases with a total death toll of 29. In Vietnam, they have confirmed 2.395 cases, with a total death toll of 35 [7].

Uniquely, Cambodia has confirmed a total of 593 cases of Covid-19, however, all of those confirmed cases managed to recover, and there are no deaths due to Covid in the said country according to the WHO. In Brunei Darussalam, there has been a total of 185 confirmed cases, with a total death toll of 3 whilst 170 of those confirmed cases have recovered. As for Timor Leste, 103 lives have been infected by the coronavirus but have so far not gained any deaths, and lastly, Laos has confirmed 25 cases, but cases of death do not differ from that of Timor Leste's [7].

The Covid-19 Pandemic condition greatly impacts the global economic recess which we could see in the IMF official release that predicts the world's economic output in 2020 that has dwindled up to $5 \%$, or almost $2 \%$ worst than initially predicted as of April. In the newest report which was released towards the end of June 2020, stated that with the said recess, the world will lose economic output for up to 12 trillion US dollars in two years times [8]. The closing of businesses worldwide causes millions of unemployment, and the main European economy has dwindled up to 2 digits in the biggest crisis since the great depression 100 years ago. According to the data presented by the newest World Economic Outlook the post-pandemic recovery prospect is uncertain due to the unpredictable nature of the covid-19 infection, data from IMF has also predicted that only 5,4\% of Gross Domestic Products will recover in 2021 [9].

Due to the Covid-19 pandemic, the extreme poverty category is predicted to increase this year, around 115 million people will be categorized into said category. This increase in the number of extreme poverty is written down to be the first since 1998 or the last two decades, Back then, the economic crisis amongst Asian Nations shook the global economy. In this situation, the World Bank stated that they shall henceforth continuously provide loans for up to trillions of rupiah to developing states [10].

The World Bank defined people experiencing extreme poverty as those who are living with less than 1,9 dollars or 28.000 rupiahs per day, The World Bank also stated that the pandemic triggers a plethora of conflicts, including those that are associated with the climate change issue. The effects of the pandemic are deemed as an obstruction to limit poverty. As of 2021, according to the World Bank, the number of people living under extreme poverty will increase to up to 150 people, even though before the pandemic occurred, the number of extreme poverty has dwindled up to $7,9 \%$ in 2020. However, now poverty will affect $9,1 \%$ and $9,4 \%$ of the entire worldwide population. This percentage is shown in the poverty and prosperity with the Worl Bank report [10]. Hereby is the data released by the World Bank in regards to global extreme poverty [10]: 


\section{Extreme poverty rising for the first time in 20 years \\ Poverty rates (\%) and number of poor people (millions) living on less than \$1.90/day}

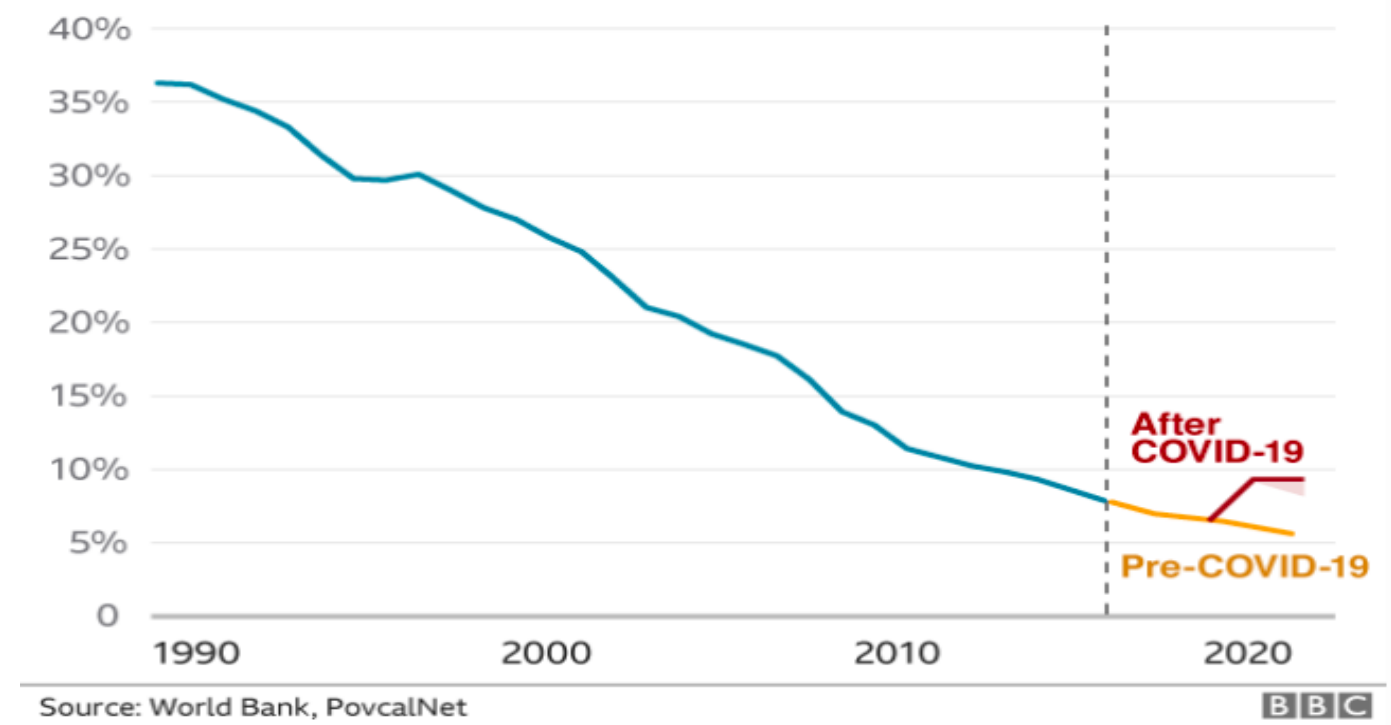

Fig. 1. The percentage of poverty and prosperity with the Worl Bank.

In response to the Covid-19 pandemic, the Indonesian Government has since implemented limitations with the social distancing policy, and the physical distancing policy since early March 2020. These policies have successfully lowered activities drastically and limited the mobilization of people in Jabodetabek and big cities [11].

Hereby is the data in regards to the economic condition of Indonesia based on the date that was released by the Central Bureau of Statistics (BPS) [12]:

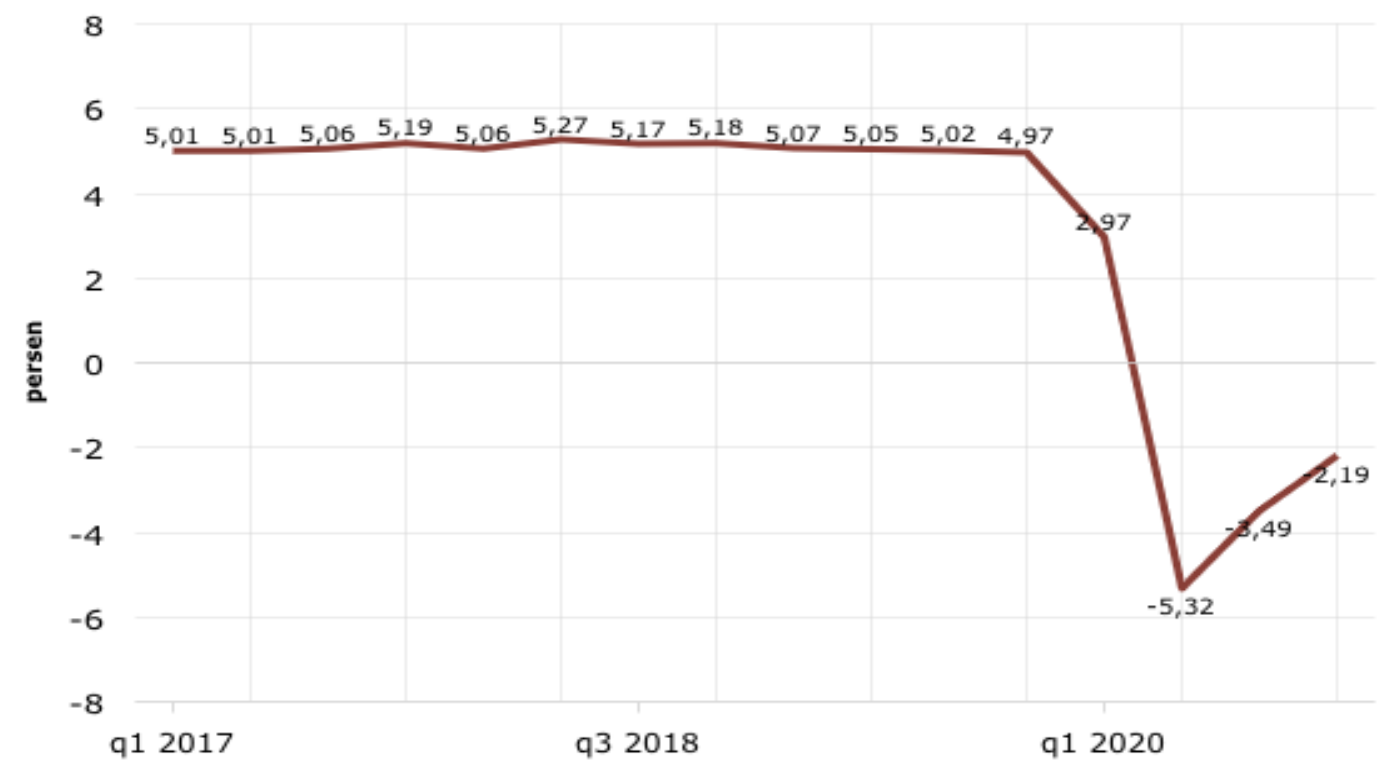

Fig. 2. Indonesia's Annual Gross Domestic Product Growth Rate (Year on Year/YoY) [12].

The Covid-19 pandemic greatly affects the Indonesian economy to the point of the recession, the Statistic Centre Body (BPS) recorded the Indonesian economy statistic in the third quarter of 2020 to be
$3,49 \%$ (year on year/yoy). With this, Indonesia has experienced a second-quarter contraction consecutively. Even so, the economic development in the current quarter still greatly differs positively 
compared to that of the second quarter of 2020 which set a record of negative growth of up to $5,32 \%$ (yoy). This is triggered by the easing of grand-scale social limitations in several regions.

The effects of the pandemic on the economic condition in Indonesia according to the research and technology Ministry namely Bambang Brodjonegoro who stated in the Indonesia Economic Outlook show 2021, the contraction of the economic growth of Indonesia in 2020 was caused by the Covid-19 pandemic. The domestic economic growth was recorded $-2,07 \%$, it became one of the worst or the firstever since 1998, The cause of the contraction was not due to the global economic crisis, but due to Covid-19 [13].

The Covid-19 pandemic has affected the Indonesian economy on several grounds, such as (1) difficulty of finding occupations (2) An abundance of employees that has to work from home without pay (3) the emergence of criminal acts in several regions (4) the country experience a great deal of loss [14].

The current condition pushes the momentum to show solidarity, to act responsibly, and to work together to reach a unanimous goal which is to secure food supply, sustain food and nutrients, and also increase the livelihood of people all across the world. There is not a single country that could face this challenge alone, therefore international cooperation is a must for all governments to assess the current global issue, Cooperation between states especially cooperation between states in the same region covers coordination, exchange of information, and experiences in regards to the success of best practices implementation in other states. There are a lot of things categorized as the main subject of a conversation such as the steps to mitigate in regards to health, economic countermeasures as a form of effort to limit poverty, and establishing sustainability and securement of travels.

Based on the illustration, the formulation of the problems to this article is how the position, function, and authority of ASEAN as an international organization, also the collaboration that has been conducted by ASEAN to assess the crises presented by the COVID-19 pandemic.

\section{DISCUSSION}

\section{A. ASEAN's Position as an International Organization}

In essence, the existence of international organizations is an impetus to permanently enhance and institutionalize international cooperation to achieve common goals [15]. International organizations formed by an agreement with any basic instrument will have a legal personality in international law. For international organizations to play a role in international relations, especially to carry out legal functions, this kind of legal personality is necessary [16]. An international organization that can show its independence means that the international organization has international communication or in other words, it can have an international personality [15]. When establishing external relations whether with member countries, host countries, non-member countries, or other international organizations, an international organization must have such a legal personality [16].

Ian Brownlie gives his opinion on the international personality of organizations by providing the following criteria [16]:

- Permanent association of states with legitimate objects, supplemented by organs. An international organization is a group of countries that are permanent with goals that are appropriate or not contrary to law, and have bodies.

- Differences, in terms of authority and legal objectives between the organization and its member countries.

- The existence of a legal force that can be implemented in the international sphere and not solely in the system of one or more countries. The legal power of international organizations can be exercised not only by international organizations in the domestic legal system of one or more countries but also at the international level.

Based on the qualifications above, ASEAN as an international organization can be classified as having a personality/legal position which can be explained as follows:

- An international organization is a group of countries that are permanent with goals that are by or not contrary to law and have bodies, so ASEAN is an inter-governmental or intergovernmental organization (IGO) established by its members, who come from 5 countries, namely Indonesia, Malaysia, Philippines, Singapore, and Thailand. ASEAN also has permanent members, and ASEAN membership is open to other Southeast Asian countries on the condition that member countries are expected to reach an agreement on the principles and objectives of the ASEAN organization as stated in the ASEAN Declaration. Following these provisions, the membership of ASEAN which originally consisted of only five founding countries was increased, in 1987 Brunei Darussalam became the sixth ASEAN member after its independence. This was followed by Vietnam on 28 July 1955. Laos and Myanmar became the 8th and 9th member states of ASEAN on 23 July 1997, and then Cambodia on 16 December 1998. The purpose of establishing ASEAN was to achieve a goal that could be maintained by 
applicable law. apply both international law and domestic law of its member countries. To achieve its goals, ASEAN has formulated things like guidelines for its implementation in the Bangkok Declaration and the ASEAN Charter. In addition, ASEAN is equipped with organs (institutional structures) that implement organizational mechanisms to achieve these goals.

- For qualifications that need to separate or distinguish legal authorities, so that there is no overlap in their enforcement, and to distinguish and separate rights and obligations as well as responsibilities related to third parties, it is necessary to distinguish between legal powers or authorities.

- Third, according to the second qualification, the organization can establish relationships with other organizations and operate independently on an international scale. Therefore, the existence of an ASEAN institutional structure and the basis for implementing an independent organization is reflected in agreements or declarations between ASEAN countries). ASEAN can separate all organizational interests from the personal interests of its country. This allows ASEAN to act independently in international relations without the interference of its member states.

According to the standard proposed by Ian Brownlie (Ian Brownlie), it is difficult to measure the international legal personality of an international organization, this is because every international organization, especially in regional organizations, has different degrees of integration between member countries [15]. This can be seen where ASEAN is still seen as a loose organization or not too strong. However, 40 years after the formation of ASEAN, ASEAN leaders signed the "ASEAN Charter" at the 13th ASEAN Summit held on 20 November 2007, thereby strengthening and transforming regional cooperation. The fundamental transformation of the ASEAN Charter is to give ASEAN legal personality. The existence of an independent ASEAN status, different from its membership status allows ASEAN to act and make agreements on its behalf, and can also sue and be prosecuted.

The ASEAN Charter is a constitutional document that contains norms, sovereignty, recognition of rights and obligations, as well as various powers in legislative, administrative, and judicial procedures. The ASEAN Charter emphasizes that member states can adopt democratic values and respect human rights, including civil and political rights. The ASEAN Charter is the ideal standard for protecting human rights under international treaties. As a constitutional document, the ASEAN Charter contains several very important elements, including [17]:
- A firm statement that ASEAN is an international organization with an international legal personality so that ASEAN can carry out its rights and obligations at the international level.

- It is clearly stated that ASEAN has the same objectives, functions, and powers as other international organizations. In other words, the charter will turn ASEAN into a rules-based organization;

- Establish legislative mechanisms, regulatory mechanisms/institutions, and procedures within ASEAN;

- Establish an enforcement mechanism or agency responsible for implementing and supervising the implementation of organizational rules and decisions;

- Establishing judicial and quasi-judicial mechanisms to interpret and implement any regulations and decisions issued by ASEAN;

- Directly, the ASEAN Charter will help promote and strengthen member countries' arrangements for ASEAN agreements, and indirectly increase regional awareness among ASEAN governments.

The establishment of ASEAN as an international organization is carried out by international law. Bangkok Declaration 1967, Kuala Lumpur Declaration 1971, ASEAN Secretariat Declaration 1976, and Treaty of Friendship and Cooperation (TAC) 1976, international agreements between these five countries are legally binding on international law [18].

As a decision, resolution, or statement, it is binding on member states. In ASEAN, the decisions taken by regional international organizations on the level of integration and cooperation among member countries within the framework of international organizations appear to be quite good and solid, it can be said that these decisions are legally binding for their members. If its members have a dispute about a matter listed in the decision of an international organization, the institution or judiciary can resolve the dispute through a judicial institution or internally within an international organization, and the institution of the judiciary can seek and apply the legal norms contained in the decision of this international organization [15].

With the entry into force of the ASEAN Charter, ASEAN has developed from a loose organization to a rule-based organization with a legal personality. The ASEAN Charter is a constitutional document that contains norms, sovereignty, affirmation of rights and obligations, as well as various powers in legislative, administrative, and judicial procedures. The ASEAN Charter also emphasizes that member states can adopt democratic values and respect human rights. The entire contents of the ASEAN Charter are still in the form of 
general descriptions and explanations, with various complete keywords. The ASEAN Charter will not automatically change many things in ASEAN, because the ASEAN Charter will continue the past habits. For example, if a consensus is not reached or there is a dispute between its member countries, ASEAN's decision-making will remain based on consensus. The ASEAN Summit will be the ultimate decision-making venue. If a dispute arises, it must be resolved amicably by the ASEAN Charter and the TAC. Therefore, the effectiveness of the ASEAN Charter can be seen from the compliance and willingness of ASEAN member countries to implement the ASEAN Charter and the provisions of the TAC [17].

\section{B. ASEAN Function}

In particular, regional organizations can basically be classified according to the nature or environment of their working methods, or according to their membership, or perhaps because they have to find groups to join. Based on the results of Lynn H. Miller and Leroy Bennet's guidelines on how to classify regional organizations, Sumaryo Suryokusumo obtained the following regional organizational divisions [18]:

- Multipurpose organizations are organizations with a wide variety of goals and activities covering the political, economic, social, cultural, and so on. The membership of this organization only extends in a geographical area such as in Africa (OAU), Latin America, the Middle East, Western Europe.

- Alliance-type organizations are organizations that have a form of military or political cooperation, the purpose of which is to maintain security against outside actions. For example NATO (1949), WTO (1955), ANZUS (1952), WEU (1954), and CENTO (1959).

- Functional organizations are organizations that aim to promote political, economic, and social cooperation, and they hardly participate in the security factor. For example ECSC (1952), EFTA (1960), ASEAN (1967), and others.

- United Nations Regional Commissions. The organization takes the form of committees working in the economic and social fields under the control of the Economic and Social Council. For example ECE (1947), ESCAP (1947), ECWA (1974), and others.

ASEAN is a regional organization that aims to promote economic growth, social progress, and cultural development in the Southeast Asian region through multilateral cooperation [19]. Moreover, it serves as a non-political platform to maintain peace and stability among its member states and external partners. Based on the above classification, ASEAN belongs to functional organizations, namely organizations that aim to promote political, economic, and social cooperation, and they hardly participate in the security factor.

\section{ASEAN Legal Authority}

Concerning its legal personality as an international organization, international organizations have legal rights and authority, therefore this applies to ASEAN which has the status of an international organization. The rights and authorities of international organizations include the following [20]:

"The right to enter into international agreements with non-member states on matters within the province of the organization. Agreements concluded by organizations have all the legally binding effects of international treaties. International organizations can conclude agreements with states, with each other, and with other subjects of international law [21]. In the Vienna Convention on the law of treaties between states and international organizations or between international organizations (1986), it is stated that: "The capacity of international organizations to make treaties is governed by the rules of that organization" (Article 6). Whereas the expression "organizational rules" is defined as "in particular the constituent instruments, decisions, and resolutions taken by them and the established practice of the organization" (Article 2.1, letter j).

The legal personality of ASEAN in its authority to make international agreements is confirmed in Article 41 paragraph (7) of the ASEAN Charter which states that:

"ASEAN can sign agreements with sub-regional, regional and international countries or organizations and institutions. The procedure for agreeing will be further regulated by the ASEAN Coordinating Council in consultation with the ASEAN Community Council".

The right to immunity from the jurisdiction of the State courts for the actions and activities of the organization.

The immunity of international organizations from the jurisdiction of a country has the same purpose as the immunity granted to foreign diplomatic representatives, namely to carry out their functions properly and smoothly, international organizations have immunity from the jurisdiction of the host state of each member state [22].

The ASEAN Charter also explains the immunities and privileges of ASEAN which are stated in Article 17, namely:

"ASEAN has immunities and privileges in the territory of Member States as necessary to achieve its objectives. Immunities and privileges will be regulated in separate agreements between ASEAN and the host Member State". 
The right to protection for all agents of the organization acting on the territory of third countries in their official capacity as international civil servants.

The right to make international claims to obtain reparations for any damage caused by member states or by third countries to the assets of the organization or its officials acting on behalf of the organization.

\section{Cooperation between ASEAN Countries to Overcome the COVID-19 Pandemic}

Several efforts have been discussed at the regional level by ASEAN to overcome the COVID-19 pandemic which has spread throughout the country, especially in the ASEAN Region. For example, on 19 February 2020, ASEAN Defense Ministers met in Hanoi, resulting in a Joint Statement on Defense Cooperation against Disease Outbreak [23]. On March 10, 2020, ASEAN Economic Ministers gathered in Da Nang, Vietnam, made a Joint Statement and determined to remain committed to keeping ASEAN markets open for trade and investment to mitigate the economic impact of COVID-19 [24]. On April 14, 2020, the Special ASEAN Summit (Summit) through a virtual conference resulted in the Declaration of the Special ASEAN Summit on Coronavirus Disease 2019 (COVID-19). Furthermore, on the same day, the ASEAN Plus Three (APT) meeting was also held virtually, attended by President Xi Jinping, Prime Minister Shinzo Abe, and President Moon Jae-in [25]. The result of the meeting was a commitment to deal with the outbreak and prepare for post-down recovery both socially and economically.

The leaders of Southeast Asian countries then agreed to establish the ASEAN COVID-19 Response Fund to secure the availability of essential medical supplies and equipment in the region [26]. The fund itself is a reallocation of available funds, technical and financial support from ASEAN partners, especially ASEAN Plus One and ASEAN Plus Three [27]. This is accompanied by a commitment not to restrict the flow of unnecessary goods, especially strategic items to deal with COVID-19 such as medicines, food, and necessities [25]. The commitments in the recent declaration reflect that ASEAN has the potential, especially in terms of goodwill and a framework or basis for cooperation, to combat the virus at the regional level.

Not only that, the ASEAN Ministers Responsible for Information (AMRI) also adopted a Joint Statement to Minimize the Negative Effects of COVID-19 on August 25, 2020. The Joint Statement is the Information Sector's commitment to respond to the negative impact of COVID-19 by eradicating fake news and misinformation. related to the pandemic and improve effective ASEAN public communication through media and information cooperation as well as mechanisms during the pandemic. Through the Joint Statement, AMRI decided to encourage [28]:
- Regular exchange of updates and official information.

- Develop regional guidelines and common platforms to facilitate timely information sharing, improve information mechanisms and working groups.

- Encourage effective and transparent public communication, promote media ethics and social responsibility among the media.

- Encouraging the improvement of media and information literacy and digital competence.

- Support the use of digital technology.

- Encourage the development of initiatives and projects related to risk or crisis communication.

- Strengthen media and information cooperation.

Therefore, it is clear that ASEAN has the potential to respond to COVID 19 through regional efforts. All of the above-mentioned potentials can enable ASEAN member countries to fulfill their commitment to cooperation at the regional level. If this commitment is fulfilled effectively, it will certainly help the national interests of each member country. However, if member countries do not take advantage of this potential, then this potential will be in vain. Even if there is such potential, there must be regional efforts that are ineffective, inefficient, and do not even have a real chance to be realized. If member states fail to fulfill their cooperation commitments, these declarations and goodwill will be meaningless. Therefore, the good faith of ASEAN members is also important to maintain in a joint effort so that they can help each other against the COVID-19 outbreak [29].

In addition, they are also willing to form the ASEAN COVID 19 Response Fund to encourage regional cooperation in dealing with the virus. This commitment can increase cooperation motivation, prevent free or disabled riding behavior, and increase positive expectations that all member countries are ready to cooperate. Furthermore, compared to the rest of the international community, ASEAN as a regional organization has a relatively limited role as an arena and instrument for its members. This situation can increase efficiency, strengthen coordination and increase the possibilities of regional efforts themselves. ASEAN also has experience working with China, Japan, and South Korea in non-traditional security fields. Experience and relationships with these three partners can be important factors and modalities for the regional response to COVID-19, as the recent ASEAN meetings also incorporated the ASEAN Plus Three models [30]. 
E. The Framework for International Cooperation and Diplomacy in ASEAN in Reducing Poverty and Building Resilience in Overcoming the Covid19 Pandemic Crisis

In a situation like this Covid-19 pandemic, it is necessary to restore the food and forestry sectors within an economic framework. This kind of thing applies to the whole world, including ASEAN countries [30]. This then underlies the implementation of priorities and economic recovery agreed by the Ministers of Southeast Asian countries to remain the main target of ASEAN [31]. This is in line with the objectives of the establishment of ASEAN as outlined in the Bangkok Declaration, namely increasing social progress, economic growth, and developing member countries cultures, as well as promoting peace at the Southeast Asian regional level [32].

This goal is also stated in the ASEAN Comprehensive Recovery Framework (ACRF) which was initiated by the ASEAN Secretariat in 2020. Initially, on April 14, 2020, a meeting entitled the ASEAN Comprehensive Recovery Framework was initiated to develop collaborative efforts to recover the Southeast Asia region due to the COVID-19 pandemic. 19. The ASEAN Secretariat presented the basic concept of the ASEAN Comprehensive Recovery Framework at the meeting, in which the main mandate of the establishment of the Framework was the recovery of the Southeast Asian region due to the impacts caused by Covid-19. The basis of the ACRF at the meeting, in which the main mandate of the establishment of the Framework was the selection of the Southeast Asian region due to the impacts caused by Covid-19. The formation of the ACRF itself is an implementation of the mandate of The Declaration of the Special ASEAN Summit and the 36th ASEAN Summit, which is primarily intended as an effort to recover from the impacts caused by the COVID-19 pandemic in the Southeast Asia region [33]. ACRF itself is expected to create a productive and healthy ASEAN [34].

In the format of the collaboration, there will be two documents, the first is the recovery framework and the second is the implementation plan. The recovery framework document will discuss COVID-19 in the ASEAN context, approaches, and principles, handling strategies, handling priorities, and supporting factors. And for the implementation plan document, the substance that is regulated is plans made by sectoral bodies, plans/national recovery measures which can be periodically updated to be used as a basis for monitoring the recovery of the Southeast Asian region after the COVID-19 pandemic [33].

It can be said that the ACRF is also the embodiment of the spirit of ASEAN cooperation which is characterized by deliberation, shared interests, and mutual assistance. By being poured into the ACRF this effort will have a clear legal basis and legal certainty in economic recovery in Southeast Asian countries [35].
As stated in the book "einführung in die rechtswissenschaften" by Gustav Radbruch, this ACRF not only obtains legal certainty but can also provide justice and benefits [36].

For the value of benefits contained in the ACRF, there are six main things. First, the ACRF will focus on prioritizing strategies to support the recovery of ASEAN countries from the impact of the Covid-19 pandemic. This point will discuss which points should be prioritized, accelerated, highlighted, and proposed a program. The prioritized points include improving public health, strengthening public security, the trade sector in this case the potential for intra-ASEAN trade, and wider economic integration, accelerating the transformation of digitalization.

The second point of the ACRF is to balance the need to earn income with saving people's lives. This concept requires that public health and security should not be sacrificed to restore the community's economy. Efforts to prevent the virus must be carried out in tandem with the consideration of the welfare of the community in a targeted manner by taking into account the resources and also the impact that will be faced by the actions taken. This allows ASEAN to bounce back better and build a more resilient future. The forms of implementation that can be done include creative solutions and new mindsets that must be designed and created by all stakeholders in each country. This will lead to the recovery process and further regional cooperation and integration in ASEAN. In general, at this point it will depend on the will and commitment of ASEAN member countries and supporting factors, one of which is the contribution of various ASEAN stakeholders.

In the next point, the ACRF will focus on strategies that have a very broad and significant impact on the recovery effort. Which political power here will greatly affect the strategy. Another point also explains that the ACRF must be pragmatic for the sake of strategies and priorities that are ready to be implemented. In its journey, ASEAN Community Councils became the party assigned by ASEAN Leaders to immediately draw up a comprehensive recovery plan. In substance, the ASEAN Community Councils plan to design several inter-sectoral supporting factors that will be regulated in this document, namely (1) policy measures and responses; (2) financing and resource mobilization; (3) institutions and governance mechanisms; (4) stakeholder engagement and partnerships; and (5) effective monitoring.

ACRF must also be inclusive, both in concept and in implementation. This regulation must provide guarantees for vulnerable groups and sectors most affected by the pandemic, which in the end does not cause widening inequality and inequality. In other words, ACRF must benefit and involve all levels of society in this recovery effort in an inclusive and resilient future. The inclusiveness that is encouraged in 
this case is the main thing from each ASEAN member itself, but this must also be encouraged by a collaboration involving the private sector, public networks, the world of health, and also resources in ensuring national, regional, and international resilience.

The last point is the implementation phase of the ACRF regulation. This point emphasizes that the ACRF is based on a scalable program. Later it is hoped that any progress from its implementation can be monitored and measured by periodic assessments. If it is in line, the estuary of all that must be present the possibilities for the necessary target adjustments [37].

To recover Southeast Asian countries due to the Covid-19 pandemic, it will certainly take years to restore the potential of several sectors. Judging from the report from the Central Statistics Agency, economic growth in Indonesia in the second quarter of 2020 decreased compared to the previous period, it was recorded that in the second period of 2020 economic growth touched minus 5.32 percent while in the previous period economic growth was at 5.02 percent [38]. This decline in economic growth has an impact on the business world as well as industry, it is recorded in the employment aspect, both in the formal and informal sectors, a lot of workers are affected by layoffs due to this pandemic [39]

Not only in the business and industrial world, but the MSME economic sector also faces challenges and needs further attention from the Government. This is due to the high dependence between economic sectors and the recovery of certain sectors. MSMEs are a sector that needs attention given that this sector has a very strategic contribution to the income of ASEAN countries [40]. Not only that, but MSMEs also provide opportunities for job creation to boost a country's GDP. In recent years, Indonesia's GDP has been dominated by the role of the MSME sector [41].

The tourism sector is also experiencing a very real impact from the COVID-19 pandemic. You can imagine how the circulation of money from the transportation sector, lodging, and also the creative economy of the local community must stop operating machines because of the loss of tourists both local and foreign who come to their area. So far, the tourism sector has been able to absorb more than 13 million workers, and this figure does not include derivatives formed under this industry [42]. Cumulatively compared to 2019 foreign tourist visits to Indonesia decreased by $59.96 \%$ (3.09 million people) from January to June 2020 [43].

\section{F. Implementation of the Framework for} International Cooperation and Diplomacy in ASEAN in Reducing Poverty and Building Resilience in Overcoming the Covid-19 Pandemic Crisis

One of the implementations of the ACRF is through increasing the capacity of public health services that enable food and nutrition security to be ensured in an emergency as well as health emergency response efforts. Efforts made from this implementation include: 1) finalizing the ASEAN guidelines on traceability systems for food and feed; 2) establishing an ASEAN center for emergencies and emerging diseases in public health; 3) Providing scientific advice to develop evidence-based food safety risk management measures; 4) Increase the use of appropriate mechanisms for sharing food safety information and rapid response in food safety problems or crises [44].

Another form of ACRF implementation is to ensure food security, food security, and community nutrition. Its concrete forms include 1) utilizing the Tier 3 APTERR Program [45], this effort is carried out to prevent the possibility of areas affected by the COVID19 outbreak experiencing food shortages and ensuring food security. Each ASEAN country will become a stockpiling area to ensure the availability of rice reserves. 2) Signing the ASEAN Food Safety Regulatory Framework Agreement (AFSRF) [44]. AFSRF itself is a regulatory framework that regulates food safety in the ASEAN Region [46].

Food handling becomes fundamental when we realize that food stability will have an impact on the stability and security of a country [47]. The food security and stability index itself has nine indicators, namely 1) the ratio of normative consumption per capita to net availability; 2) Percentage of population living below the poverty line; 3 ) The percentage of households with the proportion of expenditure on food more than 65 percent of the total expenditure; 4) Percentage of households without access to electricity; 5) The average length of schooling for women is over 15 years; 6) Percentage of households without access to clean water; 7) Ratio of population per health worker to population density level; 8) Percentage of under-fives with below standard height (stunting); 9) Life expectancy at birth [48]. But often farmers as proponents of food stability must be faced with problems that rage independently without assistance from the government [49]. This of course will have implications for the selling price of these food products, with prices that are difficult to reach by certain individuals, food security will remain in the fragile category [50]. 
TABLE I. RANKING AND SCORES PROVINCIAL FoOD SECURITY INDEX 2019

\begin{tabular}{|c|l|l|c|l|l|}
\hline Rank & \multicolumn{1}{|c|}{ Province } & Score & Rank & \multicolumn{1}{|c|}{ Province } & Score \\
\hline 1 & Bali & 85,15 & 18 & Gorontalo & 69,06 \\
\hline 2 & D.I. Yogyakarta & 83,63 & 19 & Jambi & 68,23 \\
\hline 3 & North Sulawesi & 81,44 & 20 & Central Sulawesi & 68,17 \\
\hline 4 & Central Java & 78,85 & 21 & DKI Jakarta & 66,87 \\
\hline 5 & South Sulawesi & 78,69 & 22 & North Mauku & 66,58 \\
\hline 6 & Southeast Sulawesi & 76,99 & 23 & Aceh & 66,22 \\
\hline 7 & East Kalimantan & 76,90 & 24 & West Nusa Tenggara & 66,43 \\
\hline 8 & West Java & 76,44 & 25 & Riau & 62,37 \\
\hline 9 & West Sumatera & 75,43 & 26 & Bengkulu & 61,78 \\
\hline 10 & South Kalimantan & 74,71 & 27 & West Sulawesi & 60,37 \\
\hline 11 & Banten & 74,47 & 28 & Riau Islands & 59,26 \\
\hline 12 & East Java & 73,71 & 29 & Bangka Belitung Islands & 56,03 \\
\hline 13 & North Kalimantan & 73,12 & 30 & West Kalimantan & 55,17 \\
\hline 14 & Central Kalimantan & 71,57 & 31 & Maluku & 52,35 \\
\hline 15 & Lampung & 71,36 & 32 & East Nusa Tenggara & 50,69 \\
\hline 16 & North Sumatera & 69,81 & 33 & West Papua & 30,12 \\
\hline 17 & South Sumatera & 69,30 & 34 & Papua & 25,13 \\
\hline
\end{tabular}

This data is food security data for all provinces in Indonesia in 2019. With the narrative above which describes the decline in economic growth, the number of people who have been laid off and businesses have gone out of business, the ranking and score of food security in 2020 until 2021 will be in line with the decline. Or in other words, the food security index in each province will drop considerably compared to the figures in 2019. It is recorded in the 2020 Global Food Security Index that Indonesia's Food Security Index 2020 Global Food Security Index has dropped three places, which was originally in position 62 out of a total of 113 . countries, currently down to 65 th position [51].

As a concrete effort in reinforcing food security, the Government of Indonesia itself has made several efforts. The provision of free vaccines to the general public is one of the food security programs. Judging from the above indicators, the provision of free vaccines to the community will be highly correlated with life expectancy, which is one of the nine indicators of food security and stability index. In addition, the government has also formed a BUMN holding in the context of efficiency, synergy, non-overlapping harmony, and distribution of food imports to create national food security. The percentage of households without access to electricity as an indicator of food security also makes the government take steps to provide subsidies for electricity users to the poor [52]. Another step taken by the Government of Indonesia in tackling food security in the country is the provision of basic food assistance and cash to help people survive during a pandemic [53].

Another urgency of this food stability itself is the fact that Southeast Asian countries are agricultural countries [54]. It is very disappointing if this sector is forgotten to be prioritized by ASEAN. Moreover, Southeast Asia has a dense population, so food stability will be very much needed [55].

\section{CONCLUSION}

ASEAN is a regional organization that aims to promote economic growth, social progress, and cultural development in the Southeast Asian region through multilateral cooperation. Moreover, it serves as a nonpolitical platform to maintain peace and stability among its member states and external partners. Several efforts have been discussed at the regional level by ASEAN to overcome the COVID-19 pandemic which has spread throughout the country, especially in the ASEAN Region. For example, the Joint Statement on Defense Cooperation against Disease Outbreak.

On April 14, 2020, the Special ASEAN Summit (Summit) through a virtual conference resulted in the Declaration of the Special ASEAN Summit on Coronavirus Disease 2019 (COVID-19). Furthermore, on the same day, the ASEAN Plus Three (APT) meeting was also held virtually. In addition, there are also other collaborations such as the ASEAN Comprehensive Recovery Framework (ACRF) which was initiated by the ASEAN Secretariat in 2020.

ASEAN as a regional organization aims to encourage economic growth, social progress, and cultural development in the Southeast Asian region through multilateral cooperation. In addition, ASEAN serves as a non-political platform to maintain peace and stability among its member states and external partners. The rights and authorities of international organizations include the following:

- The right to enter into international agreements with non-member states on matters within the province of the organization.

- The right to immunity from the jurisdiction of the State courts for the actions and activities of the organization.

- The right to protection for all agents of the organization acting on the territory of third 
countries in their official capacity as international civil servants.

- The right to make international claims to obtain reparations for any damage caused by member states or by third countries to the assets of the organization or its officials acting on behalf of the organization.

ASEAN already has the potential of its members to work together and fight COVID-19 together. The potential here can be interpreted as an ASEAN modality to encourage the realization of cooperation between countries in facing regional challenges. The first potential is the goodwill of ASEAN members, reflected in the Declaration of the Special ASEAN Summit on Coronavirus Disease 2019 (COVID-19). The commitments in the statement can be used as a basis for easing the beggar thy neighbor policy in times of crisis where member states agree not to impose unnecessary restrictions on the circulation of goods such as medical equipment.

Several efforts have been discussed at the regional level by ASEAN to overcome the COVID-19 pandemic which has spread throughout the country, especially in the ASEAN Region. For example, the Joint Statement on Defense Cooperation against Disease Outbreak. On April 14, 2020, the Special ASEAN Summit (Summit) through a virtual conference resulted in the Declaration of the Special ASEAN Summit on Coronavirus Disease 2019 (COVID-19). Furthermore, on the same day, the ASEAN Plus Three (APT) meeting. There is also another collaboration, namely the ASEAN Comprehensive Recovery Framework (ACRF) which was initiated by the ASEAN Secretariat in 2020.

\section{REFERENCES}

11] Setnas ASEAN. "ASEAN Perkuat Keamanan Pangan D Kawasan Melalui ASEAN Health Cluster 4 Ensuring Food Safety". http://www.setnas-asean.id/siaran-pers/read/aseanperkuat-keamanan-pangan-di-kawasan-melalui-asean-healthcluster-4-ensuring-food-safety.

[2] Koesrianti. Association of South East Asian Nations (ASEAN), Sejarah Konstitusi dan Integrasi Kawasan. Surabaya: Airlangga University Press. 2014.

[3] R. Abudi, Y. Mokodompis, and A. N. Magulili. "Stigma Terhadap Orang Positif Covid-19," Jambura Journal of Health Sciences and Research 2, no. 2 (2020): 12. https://doi.org/10.35971/jjhsr.v2i2.6012.

[4] WHO. "Naming the coronavirus disease (COVID-19) and the virus that causes it." World Health Orgnatization (WHO), 2020. https://www.who.int/emergencies/diseases/novelcoronavirus-2019/technical-guidance/naming-thecoronavirus-disease-(covid-2019)-and-the-virus-that-causesit.

[5] WHO. "Pertanyaan dan jawaban terkait Coronavirus," World Health Orgnatization (WHO), 2020. https://www.who.int/indonesia/news/novel-coronavirus/qafor-public.

[6] WHO. "WHO Director-General's remarks at the media briefing on 2019-nCoV on 11 February 2020," World Health Orgnatization (WHO), 2020, https://www.who.int/dg/speeches/detail/who-director-general- s-remarks-at-the-media-briefing-on-2019-ncov-on-11february-2020.

[7] WHO. Situation by Region, Country, Territory \& Area. Retreived from https://covid19.who.int/table.

[8] BBC News. Krisis ekonomi akibat Covid-19: IMF perkirakan 'luka ekonomi' karena krisis global akibat pandemi virus corona lebih buruk dari perkiraan. 2020. Retreived from https://www.bbc.com/indonesia/dunia-53168814

[9] OkeFinance. Krisis Ekonomi Akibat Pandemi Covid-19 Kerugian Capai USD 12 Triliun. 2020. Retreived from https://economy.okezone.com/read/2020/06/25/20/2236212/kr isis-ekonomi-akibat-pandemi-covid-19-kerugian-capai-usd12triliun.

[10] BBC News. Pandemi Covid-19 sebabkan kemiskinan ekstrem di seluruh dunia akan melonjak untuk pertama kalinya sejak tahun $\quad 1998.2020 . \quad$ Retreived from https://www.bbc.com/indonesia/dunia-54453523.

[11] W. Hadiwardoyo. "Kerugian ekonomi nasional akibat pandemi Covid-19." Baskara: Journal of Business and Entrepreneurship 2.2. 2020. 83-92.

[12] D. H. Jayani. Indonesia Resesi, Ekonomi Indonesia Tumbuh Minus 3,49\% Kuartal III 2020. Databoks. 2020. Retreived from https://databoks.katadata.co.id/datapublish/2020/11/05/indone sia-resesi-ekonomi-indonesia-tumbuh-minus-349-kuartal-iii2020.

[13] D. A. Putra. Menristek Bambang Sebut Covid-19 Jadi Krisis Ekonomi Terbesar yang Pernah Ada. 2021. Retreived from https://www.merdeka.com/uang/menristek-bambang-sebutcovid-19-jadi-krisis-ekonomi-terbesar-yang-pernah-ada.html.

[14] M. A. Putri, R. Septyanani, and A. P. A. Santoso. "Dampak Covid-19 Pada Perekonomian Indonesia." Prosiding HUBISINTEK 1. 2020. 198-198.

[15] I. W. Parthiana. Pengantar Hukum Internasional. Bandung: Mandar Maju. 2003.

[16] A. M. Suherman. Organisasi Internasional dan Integrasi Ekonomi Regional Dalam Perspektif Hukum dan Globalisasi. Jakarta: PT Ghalia Indonesia. 2003.

[17] E. Farida. Efektivitas Piagam Asean (Asean Charter) Bagi Asean Sebagai Organisasi Internasional. Jurnal Ilmu Hukum QISTIE 3, no. 3. 2009

[18] S. Suryokusumo. Studi Kasus Hukum Organisasi Internasional. Bandung: Alumni. 1997.

[19] ASEAN. “About ASEAN.” ASEAN. Access 16 Januari 2021. https://asean.org/asean/about-asean/.

[20] A. Cassese. International Law. Second. United Kingdom: Oxford University Press. 2005.

[21] N. Purda. Aspects of International Legal Personality of International Organizations. Challenges of the Knowledge Society. Legal Sciences 2. 2012. 891-900.

[22] D. K. Pratiwi. Pelaksanaan Prinsip Yuridiksi Universal Mengenai Pemberantasan Kejahatan Perompakan Laut Di Wilayah Indonesia. Jurnal Selat 5, no. 1. 2017. 2354-8649.

[23] ASEAN. Joint Statement by The ASEAN Defence Ministers on Defense Cooperation Against Disease Outbreaks. ASEAN, 20 Februari 2020. https://asean.org/joint-statement-aseandefence-ministers-defense-cooperation-disease-outbreaks/.

[24] ASEAN. Strengthening ASEAN'S Economic Resilience in Response to The Outbreak of The Coronavirus Disease (COVID-19). ASEAN. 10 Maret 2020. https://asean.org/strengthening-aseans-economic-resilienceresponse-outbreak-coronavirus-disease-covid-19/.

[25] ASEAN. Declaration of the Special ASEAN Summit on Coronavirus Disease 2019 (COVID-19). ASEAN. 14 April 2020. https://asean.org/declaration-special-asean-summitcoronavirus-disease-2019-covid-19/.

[26] D. Septiari. Leaders support establishment of ASEAN COVID19 response fund. The Jakarta Post. accessed on January 2021. 
https://www.thejakartapost.com/seasia/2020/04/14/leaderssupport-establishment-of-asean-covid-19-response-fund.html.

[27] CNN Indonesia. Jokowi Usul Bentuk ASEAN Covid-19 Response Fund. CNN Indonesia, 14 April 2020. https://www.cnnindonesia.com/ekonomi/20200414193511532-493566/jokowi-usul-bentuk-asean-covid-19-responsefund.

[28] ASEAN. ASEAN Ministers Responsible for Information adopt joint statement to minimise negative effects of COVID-19. ASEAN, 9 September 2020. https://asean.org/asean-ministersresponsible-information-adopt-joint-statement-minimisenegative-effects-covid-19/.

[29] R. Widian, and V. Omega. ASEAN Regional Potentials for Combating COVID-19. Jurnal Ilmiah Hubungan Internasional, 2020.

[30] F. Febrinastri. Pemulihan Bidang Pangan Perlu Dilakukan dalam Kerangka Ekonomi Global. Suara.com. Retreived from https://www.suara.com/bisnis/2020/10/22/160613/pemulihanbidang-pangan-perlu-dilakukan-dalam-kerangka-ekonomiglobal.

[31] Ministry od Trade. Percepat Pemulihan Ekonomi ASEAN di Masa Pandemi Covid-19, Indonesia Dukung Kerja Sama Transformasi Digital dan Penanganan Hambatan Nontarif. Jakrata: Ministry of Trade of the Republic of Indonesia. 2020. Retreived from https://www.kemendag.go.id/storage/article uploads/JkOHf WrmO2kKIP0t2AEWDeDmHsR0VGPelJdSxxSA.pdf

[32] P. H. Purwandoko, and Sasmini, Prospek Pembentukan Asean Intergovernmental Commission On Human Rights (AICHR) (Harapan Baru, Kelemahan dan Solusi), Yustisia, Vol. 1, No. 2, 2012. 122.

[33] AEC Council Minister Indonesia. Pertemuan ASEAN Comprehensive Recovery Framework Dalam Menyusun Kerjasama Pemulihan Ekonomi Pasca Pandemik Covid-19. Retreived from https://meaindonesia.ekon.go.id/pertemuanasean-comprehensive-recovery-framework-dalam-menyusunkerjasama-pemulihan-ekonomi-pasca-pandemik-covid-19/

[34] Antara News. Pertemuan Menteri Asean Kementan Dorong Pemulihan Pangan Global. Retreived from https://www.antaranews.com/berita/1798849/pertemuanmenteri-asean-kementan-dorong-pemulihan-pangan-global.

[35] Triono. Peran Asean Dalam Penyelesaian Konflik Etnis Rohingnya. Jurnal TAPIs, Vol. 10, No. 2. 2014. 4

[36] M. Julyano, and A. Y. Sulistyawan, Pemahaman Terhadap Asas Kepastian Hukum Melalui Konstruksi Penalaran Positivisme Hukum. Jurnal Crepido, Vol. 01, No. 01. 2019. 13.

[37] ASEAN. ASEAN Comprehensive Recovery Framework.

[38] M. Awaluddin. Pergeseran Negatif Kondisi Ekonomi Di Kalimantan Timur Pasca Penyebaran Virus Corona (Covid 19). Jurnal Eksis, Vol. 17, No. 1. 2021. 8-9.

[39] Binus University. Penurunan Ekonomi Di Indonesia Pada Masa Pandemi Yang Berpengaruh Pada Pekerjaan Masyarakat. Retreived from https://studentactivity.binus.ac.id/tfi/2021/03/penurunan-ekonomi-diindonesia-pada-masa-pandemi-yang-berpengaruh-padapekerjaan-masyarakat/.

[40] F. Nuraini, R. Maharani and Andrianto, Strategi Peningkatan Daya Saing UMKM Dan Koperasi Dalam Menghadapi AEC (ASEAN Economic Community): Suatu Telaah Kepustakaan. Prosiding Seminar Nasional Ekonomi dan Bisnis \& Call For Paper FEB UMSIDA. 2016. 491.

[41] E. Pudyastiwi, and A. Djatmiko. Usaha Mikro, Kecil Dan Menengah (UMKM) Indonesia Dalam Menghadapi
Perdagangan Bebas Di ASEAN. Jurnal Pendidikan Kewarganegaraan Undiksha, Vol. 8, No. 2. 2020. 144.

[42] I. D. G. Sugihamretha. Respon Kebijakan: Mitigasi Dampak Wabah Covid-19 Pada Sektor Pariwisata. The Indonesian Journal of Development Planning, Vol. IV, No. 2. 2020. 195.

[43] V. U. Kmasbiran. Dampak Pandemi Covid-19 Terhadap Pariwisata Sumatera Barat. Jurnal Pembangunan Nagari, Vol. 5, No. 2. 2020. 148

[44] ASEAN. Implementation Plan ASEAN Comprehensive Recovery Framework.

[45] The APTERR Tier 3 program is a program that involves the release of stockpiled emergency rice stocks for severe emergencies and humanitarian responses, such as poverty alleviation and the eradication of malnutrition, to ensure food security in the region. Rice distribution under this program can be a fast track to help under automatic triggers.

[46] Asean National Secretariat. ASEAN Perkuat Keamanan Pangan di Kawasan Melalui ASEAN Health Cluster 4: Ensuring Food Safety. 2018. Retreived from http://www.setnas-asean.id/siaran-pers/read/asean-perkuatkeamanan-pangan-di-kawasan-melalui-asean-health-cluster4-ensuring-food-safety

[47] A. F. Basundoro, and F. H. Sulaeman. Meninjau Pengembangan Food Estate Sebagai Strategi Ketahanan Nasional Pada Era Pandemi Covid-19. Jurnal Kajian Lemhannas RI. 8(2). 2020. 31

[48] Food Security Agency. Indeks Ketahanan Pangan Indonesia 2019. Jakarta. Ministry of Agriculture. Retreived from http://bkp.pertanian.go.id/storage/app/media/Bahan\%202020/ IKP\%202019\%20FINAL.pdf

[49] M. Syawie. Ketahanan Pangan Dan Kesejahteraan Petani (Food Security and Farmers Well-being). Informasi, Vol. 17, No. 03. 2012. 159.

[50] S. Tajerin, and R. Yusuf. Tingkat Kesejahteraan Dan Ketahanan Pangan Rumahtangga Nelayan Miskin: Studi Kasus di Kelurahan Marunda Baru, DKI Jakarta dan Desa Tanjung Pasir, Banten. J. Sosek KP, Vol. 6, No. 1. 2011. 85-86.

[51] Ekonomi Bisnis. Indeks Ketahanan Pangan Global 2020 Posisi Indonesia Turun $\mathrm{Ke}$ 65. Retreived from https://ekonomi.bisnis.com/read/20210313/12/1367047/indek s-ketahanan-pangan-global-2020-posisi-indonesia-turun-ke65.

[52] Warta Ekonomi. Subsidi Listrik Pln Di Tengah Pandemi Covid-19 Langkah Tepat Jaga Daya Beli Masyarakat. https://www.wartaekonomi.co.id/read336947/subsidi-listrikpln-di-tengah-pandemi-covid-19-langkah-tepat-jaga-dayabeli-masyarakat.

[53] Detik News. Rincian Bantuan PPKM Darurat Dari Uang Tunai Hingga Sembako. https://news.detik.com/berita/d5631909/rincian-bantuan-ppkm-darurat-dari-uang-tunaihingga-sembako.

[54] F. B. M. Dabukke, and M. Iqbal. Kebijakan Pembangunan Pertanian Thailand, India, Dan Jepang Serta Implikasinya Bagi Indonesia Agricultural Development Policies in Thailand, India, and Japan with Their Implications for Indonesia. Analisis Kebijakan Pertanian, Vol. 12, No. 2. 2014.

[55] W. Astari. Kebijakan Pemerintah Indonesia Dalam Mengantisipasi Perkembangan Gerakan Terorisme Di Kawasan Asia Tenggara Tahun 2010-2015. Jom FISIP, Vol. 4, No. 2. 2017. 6 . 